\title{
ORIGINAL
}

\section{Biodegradability, Hydrolytic Degradability and Builder Performance of Starch-Based Polycarboxylates Derived from Tropical Plants}

\author{
Isananto WINURSITO and Shuichi MATSUMURA \\ Faculty of Science and Technology, Keio University \\ (3-14-1, Hiyoshi, Kohoku-ku, Yokohama-shi, T223)
}

\begin{abstract}
Partially dicarboxylated polysaccharides were prepared using starch from corn, sago and tapioca and comparison was made of their biodegradability, hydrolytic degradability and builder performance in detergent formulations. The biodegradability of dicarboxylated starch sodium salt (DCstarch) depended on the dicarboxylation degree. DC-starch containing more than 75 85 mol\% unreacted glucopyranose groups in the polymer chain showed excellent biodegradation. DC-starch with high dicarboxylation degree was resistant to biodegradation but showed good builder performance in detergent formulation. Among DC-starches from corn, sago and tapioca starches, hydrolytic degradability and builder performance were essentially the same.
\end{abstract}

Key words : biodegradation, dicarboxylated starch, polycarboxylate, detergent builder, starch from tropical plant, water-soluble polymer.

\section{Introduction}

It is reported that high-molecular weight polycarboxylates showed excellent performance as dispersants and detergent builders ${ }^{1) \sim 3}$. However, they are generally highly resistant to biodegradation. It is expected that the developments of biodegradable high-molecular weight polycarboxylates are needed in the industrial field. The introduction of biodegradable segment into the functional polymer chain is one way to design environmentally acceptable biodegradable functional polymers ${ }^{4) \sim 6)}$.

Carbohydrates may serve as an attractive raw material for the preparation of high-molecular weight poly(carboxylic acid)s because they are inexpensive, renewable and biodegradable materials ${ }^{7) ~ 9)}$. Among the carbohydrates, starch is the most abundant material, and may be one of the most promising raw material in the future. Starch is mainly composed of two types of molecules, amylose and amylopectin. The composition of amylose and amylopectin in the starch has a wide variation depending on the origin of starch, plant variety, geographical conditions, etc. ${ }^{10)}$. Particularly, corn, sago and tapioca starches, which are the most promising tropical products, attracted attention as a renewable raw material in the industrial field. In 1959, dicarboxylated starches were suggested by Hofreiter et al. for use with detergents to improve washing performance ${ }^{11)}$. After this, some investigations of dicarboxylated polysaccharides were reported with respect to the synthetic methods and properties $^{12) \sim 14)}$.

We previously reported some properties of polycarboxylates obtained from amylose and amylopectin individually ${ }^{15) ~ 17)}$. However, starch composed both of amylose and amylopectin has not yet been extensively studied. In this report, starches from corn, sago and tapioca

Corresponding author : Shuichi MATSUMURA 
were partially dicarboxylated to retain biodegradable glycopyranose groups by the conversion of the vicinal diols of glycopyranose into dicarboxylates via dialdehydes and compared with respect to biodegradability, hydrolytic degradability as well as functionality.

\section{Experimental}

\subsection{Materials and measurements}

Starch samples from corn (maize, Zea mays L.), sago (from stems of several species of palms, principally Metroxylon, Arenga and Mauritia sp.) and tapioca (Manihot utilissima P., Manihot esculenta) were used in this report. The other materials were of the highest available purity and were used as purchased.

${ }^{13} \mathrm{C}$ NMR spectra were recorded with a JEOL model JNM-FX90A Fourier Transform Spectrometer operating at $22.5 \mathrm{MHz}$ with complete proton decoupling(JEOL Ltd., Tokyo, Japan). Infrared (IR) spectra were measured using a JASCO Fourier Transform Spectrometer model FT/IR-5000 (JASCO Ltd., Tokyo, Japan). Number-average molecular weight $(\bar{M} n)$ and molecular weight distributions $(\bar{M} w / \bar{M} n)$ were measured by a gel-permeation chromatographic system (GPC) with commercial GPC columns (TSK gel G5000PW+G2500PW, TOSOH Co. Ltd.) with a $0.1 \mathrm{M}$ phosphate buffer containing $0.3 \mathrm{M} \mathrm{NaCl}, \mathrm{pH} 6.8$, as eluent. The system was calibrated with a poly(ethylene oxide) standard ( $\bar{M} n: 3000-996000, \bar{M} w / \bar{M} n$ : 1.02-1.10), purchased from TOSOH Co. Ltd. (Tokyo, Japan).

\subsection{Preparation of the Partially Dicarboxylated Starches}

Partially dicarboxylated starch sodium salt (DC-starch) having various dicarboxylation degree was prepared by the partial conversion of the vicinal diol of the glucopyranose groups of starch into dicarboxylates via dialdehydes as shown in Scheme 113),17). Preparation of dicarboxylated corn starch sodium salt (DC-corn) having a number-average molecular weight $(\bar{M} n)$ of 19300 and a dicarboxylation degree of 46 mol\% [DC-corn-19300 (46)] is described as a representative.

Corn starch $(5.0 \mathrm{~g})$ was suspended in $0.10 \mathrm{M}$ aqueous sodium periodate $(145 \mathrm{~mL})$ and stirred at $4^{\circ} \mathrm{C}$ for $6 \mathrm{~h}$ in the dark. After the reaction, the suspension was filtered, washed thoroughly with chilled water, dried in vacuum below $40^{\circ} \mathrm{C}$ to obtain diformylstarch in $92.8 \%$ yield $(4.64 \mathrm{~g})$. The dialdehyde content of the product, determined by the method of Nieuwenhuizen $^{13)}$, was $47.5 \mathrm{~mol} \%$. Diformylstarch ( $4.0 \mathrm{~g}$ ) was suspended in $123 \mathrm{~mL}$ water, nitrogen was bubbled into the solution at $0^{\circ} \mathrm{C}$ for $30 \mathrm{~min}$, and a solution of $26 \mathrm{~g}$ sodium chlorite in 70 $\mathrm{mL}$ water was added to the aqueous diformylstarch. The $\mathrm{pH}$ of the solution was adjusted to 4.0 with acetic acid, and the mixture was stirred at $20^{\circ} \mathrm{C}$ for $24 \mathrm{~h}$. The temperature was then raised to $50^{\circ} \mathrm{C}$ and the reaction was allowed to continue for another $1 \mathrm{~h}$. Nitrogen was passed through the solution until a colorless solution was obtained. The $\mathrm{pH}$ of the solution was then
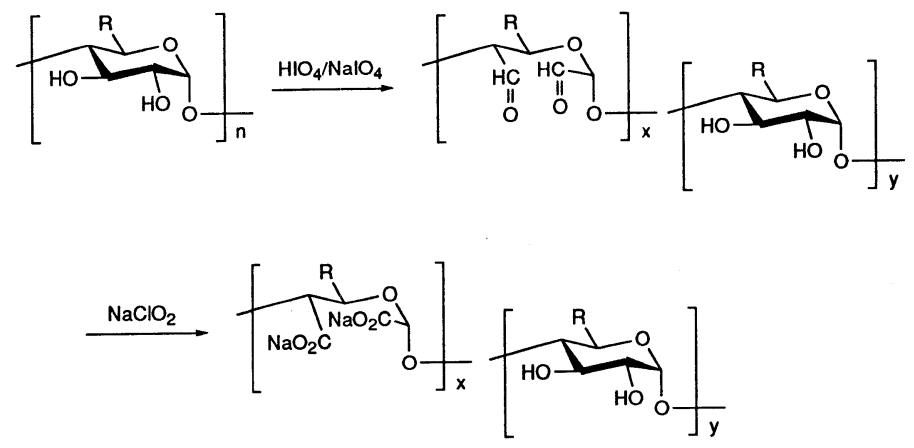

$\mathrm{R}=\mathrm{CH}_{2} \mathrm{OH}, \mathrm{CH}_{2} \mathrm{O}$

Scheme 1 
raised to 10 with $3 \mathrm{M}$ aqueous sodium hydroxide. The solution was poured slowly into a large amount of ethanol $(400 \mathrm{~mL})$ with stirring to precipitate the polymer. The precipitated polymer was dissolved in $50 \mathrm{~mL}$ of water, and the solution was then again added slowly to a large amount of ethanol $(300 \mathrm{~mL})$ with stirring to precipitate the polymer. The precipitated polymer was dissolved in $50 \mathrm{~mL}$ of water and dialyzed against distilled water for $3 \mathrm{~d}$. The insoluble precipitate was removed by filtration, and the filtrate was evaporated in vacuum before freeze-dried. Further drying was carried out at $70^{\circ} \mathrm{C}$ in vacuum to obtain $\mathrm{DC}-$ corn in $96 \%$ yield $(3.84 \mathrm{~g})$ as a white powder. The dicarboxylate content as measured according to Neale and Springfellow ${ }^{18)}$ was $41 \mathrm{~mol} \% . \bar{M} n=19300$ and $\bar{M} w / \bar{M} n=3.6$ by GPC. The following spectral data for DC-Corn-19300(46) confirm the structure. $\mathrm{IR}(\mathrm{KBr}): 3333(\mathrm{OH}), 2934\left(\mathrm{CH}_{2}\right)$, 1614,1419 (COONa), 1153, $1024 \mathrm{~cm}^{-1}(\mathrm{C}-\mathrm{O}-\mathrm{C}) .{ }^{13} \mathrm{C} \mathrm{NMR}\left(22.5 \mathrm{MHz}: \mathrm{D}_{2} \mathrm{O}\right): 61.7-63.1\left(-\mathrm{CH}_{2}{ }^{-}\right)$, 72.1-75.0 [ $\left.>\mathrm{CH}-\mathrm{CH}\left(\mathrm{CH}_{2} \mathrm{OH}\right)-\mathrm{O}^{-}\right]$, 78.2-81.7 [ $\left.>\mathrm{CH}-\mathrm{CH}\left(\mathrm{CH}_{2} \mathrm{OH}\right)-\mathrm{O}^{-},-\mathrm{CH}(\mathrm{OH})^{-}\right], 100.9-101.8$ (-O-CH-O-), 174.9-177.1 (COONa). Dicarboxylated sago starch sodium salt (DC-sago) and dicarboxylated tapioca starch sodium salt (DC-tapioca) having various degree of dicarboxylation were also obtained by a similar procedure. Typical oxidation condition and analytical data for DC-starch are shown in Table 1.

\subsection{Biodegradation Test}

Biochemical oxygen demand (BOD) was determined with a BOD tester (Model 200 and 100 F ; TAITEC Corp., Koshigaya-shi, Japan) by the oxygen consumption method basically according to the OECD Guidelines for Testing of Chemicals (301C, Modified MITI Test) ${ }^{19)}$ at $25^{\circ} \mathrm{C}$, using an activated sludge freshly obtained from a municipal sewage treatment plant in

Table-1 Typical Preparation and Analytical Data of Partially Dicarboxylated Starch (DC-Starch).

\begin{tabular}{|c|c|c|c|c|c|c|c|}
\hline \multirow[b]{2}{*}{ Compound $^{a}$} & \multicolumn{3}{|c|}{$\begin{array}{l}\text { Oxidation of starch to dialdehyde } \\
\text { by aqueous sodium periodate } b\end{array}$} & \multicolumn{4}{|c|}{$\begin{array}{l}\text { Oxidation of dialdehyde to DC-Starch } \\
\text { by aqueous sodium chlorite }\end{array}$} \\
\hline & $\begin{array}{l}\text { Concentration of } \\
\text { sodium periodate } \\
(\mathrm{M})\end{array}$ & $\begin{array}{l}\text { Yield } \\
(\%)\end{array}$ & $\begin{array}{l}\text { Dialdehyde } \\
\text { content } \\
(\text { mol\%) }\end{array}$ & $\begin{array}{l}\text { Yield } \\
(\%)\end{array}$ & $\begin{array}{c}\text { Dicarboxylate } \\
\text { content } \\
(\text { mol\% })\end{array}$ & $\bar{M} n$ & $\bar{M} w / \bar{M} n$ \\
\hline DC-Corn-11400 (7) & 0.015 & 93 & 18 & 82 & 7 & 11400 & 5.1 \\
\hline DC-Corn-27200 (29) & 0.05 & 93 & 29 & 80 & 29 & 27200 & 4.9 \\
\hline DC-Corn-19300 (46) & 0.10 & 93 & 47 & 96 & 46 & 19300 & 3.6 \\
\hline DC-Corn- $9400(77)$ & 0.20 & 76 & 96 & 95 & 77 & 9400 & 1.7 \\
\hline DC-Corn- $7500(78)$ & 0.30 & 93 & 85 & 61 & 78 & 7500 & 1.8 \\
\hline DC-Sago-14300 (10) & 0.015 & 91 & 18 & 57 & 10 & 14300 & 7.6 \\
\hline DC-Sago-18100 (23) & 0.05 & 93 & 35 & 73 & 23 & 18100 & 3.8 \\
\hline DC-Sago- 8900 (44) & 0.10 & 97 & 57 & 64 & 44 & 8900 & 2.1 \\
\hline DC-Sago-12300 (67) & 0.20 & 92 & 89 & 81 & 67 & 12300 & 1.8 \\
\hline DC-Sago-11800 (81) & 0.30 & 93 & 97 & 56 & 81 & 11800 & 1.8 \\
\hline DC-Tapioca-21100 (8) & 0.015 & 92 & 18 & 87 & 8 & 21100 & 6.3 \\
\hline DC-Tapioca-17800 (24) & 0.05 & 94 & 32 & 82 & 24 & 17800 & 2.3 \\
\hline DC-Tapioca-15800 (45) & 0.10 & 95 & 56 & 70 & 45 & 15800 & 8.0 \\
\hline DC-Tapioca-15900 (73) & 0.20 & 95 & 83 & 83 & 73 & 15900 & 2.3 \\
\hline DC-Tapioca-11400 (78) & 0.30 & 95 & 96 & 78 & 78 & 11400 & 1.6 \\
\hline
\end{tabular}

a Polymer code indicates number average molecular weight $(\bar{M} n)$ and relative dicarboxylate content in mol \% in parenthesis.

${ }^{b}$ Dialdehyde of starch was prepared by the reaction of $5.0 \mathrm{~g}$ starch with $145 \mathrm{~mL}$ aqueous $\mathrm{NaIO}_{4}$ for $6 \mathrm{~h}$ at $4^{\circ} \mathrm{C}$.

${ }^{c} \mathrm{DC}$-Starch was prepared by the reaction of dialdehyde with aqueous sodium chlorite at $\mathrm{pH} 4$ for $24 \mathrm{~h}$ at $20^{\circ} \mathrm{C}$. 
Yokohama city. The concentration of the polymer in the incubation media was $25 \mathrm{mg} / \mathrm{L}$.

\subsection{Hydrolytic Degradation}

A non-enzymatic degradation test was carried out by dissolving the polymer in buffer solutions with $\mathrm{pH}$ values of $4,5,6,8$ and 10 . The polymers at a concentration of $400 \mathrm{mg} / \mathrm{L}$ were incubated at $30^{\circ} \mathrm{C}$ in an incubator. Solutions of $0.1 \mathrm{M}$ acetate buffer at $\mathrm{pH} 4.0$ and 5.0, $0.1 \mathrm{M}$ phosphate buffer at $\mathrm{pH} 6.0,0.1 \mathrm{M}$ tris- $\mathrm{HCl}$ buffer at $\mathrm{pH}$ 8.0, and $0.1 \mathrm{M}$ glycine- $\mathrm{NaOH}$ buffer at $\mathrm{pH} 10.0$ were used for the non-enzymatic degradation test. The degradation of the polymer was analyzed by GPC, and the hydrolytic degradability was expressed by molecular weight reduction in percent given by :

molecular weight reduction $(\%)=\left[\left(\mathrm{M}_{0}-\mathrm{M}_{\mathrm{t}}\right) / \mathrm{M}_{0}\right] \times 100$

where $\mathrm{M}_{0}$ is the initial molecular weight (maximum molecular weight of GPC peak) and $\mathrm{M}_{\mathrm{t}}$ is the molecular weight (maximum molecular weight of GPC peak) after $\mathrm{t}$-day incubation.

\subsection{Detergency}

The washing experiments were performed with water of $54 \mathrm{mg} / \mathrm{L}\left(\mathrm{CaCO}_{3}\right)$ with a cloth-toliquor ratio of $1: 30$, at a temperature of $25^{\circ} \mathrm{C}$, and with a detergent concentration of $1.2 \mathrm{~g} / \mathrm{L}$. The detergency test was first conducted with a standard heavy-duty detergent formulation that contained $20 \%$ sodium dodecylbenzene sulfonate, $25 \%$ sodium tripolyphosphate (STPP) or disodium 3-oxapentanedioate (ODA), 5\% sodium silicate, 3\% sodium carbonate, $0.5 \%$ sodium carboxymethyl cellulose (CMC), and $46.5 \%$ sodium sulfate. The test was done to determine the detergency of the STPP and ODA formulation as a basis for comparison with the test polymers. In the experimental formulas, the STPP or ODA was replaced with an equal weight of the polymers. The washing efficiency of the polymers was determined in a Terg-O-Tometer as a device for simulation of home washers of the agitator type on a laboratory scale, using improved artificially soiled cotton cloth test pieces prepared by an aqueous dispersion method ${ }^{20)}$. The light reflectance of the test swatches was measured by means of an automatic reflectometer equipped with a green filter. The $K / S$ ratio $(K$, reflectivity coefficient; $S$, light scattering coefficient) was calculated using Kubelka-Munk equation ${ }^{21)}$, and the detergency was expressed according to the equation :

detergency $(\%)=(\mathrm{A}-\mathrm{B}) /(\mathrm{A}-\mathrm{C}) \times 100$

where, $\mathrm{A}, \mathrm{B}$ and $\mathrm{C}$ are the $K / S$ values of the soiled pieces, of the washed pieces and the original unsoiled pieces, respectively. The $K S$ value was expressed according to the following equation :

$$
K / S=(1-R)^{2} / 2 R
$$

where $R$ is the reflectance. The relative detergency was expressed as a value of 10 for STPP and 0 for ODA.

\subsection{Calcium Sequestration Capacity}

A calcium ion electrode (Model 93-20, Orion Research, Inc., Boston, MA) and an ion meter (IM-20E, TOA Electronic, Ltd., Tokyo, Japan) were used to measure the equilibrium calcium ion concentrations. Ten milligrams of the polymer was dissolved in $50 \mathrm{~mL}$ of $1.00 \times$ $10^{-3} \mathrm{M}$ calcium hardness solution containing a $0.08 \mathrm{M} \mathrm{KCl}$ (ion strength, $\mu=0.08$ ). The $\mathrm{pH}$ of the solution was adjusted to 9.0 at $30^{\circ} \mathrm{C}$. The electrode was immersed in the solution, which was then stirred. After $10 \mathrm{~min}$, equilibrium free calcium ion concentrations were measured, and the calcium sequestration capacity was expressed as grams of calcium ion sequestered by $100 \mathrm{~g}$ of polymer.

\section{Results and Discussion}

\subsection{Preparation of Partially Dicarboxylated Starch}

DC-starch having a varying amount of unreacted glucopyranose groups to provide enzymatically cleavable segments was prepared by the partial oxidation of corn, sago and tapioca starch using sodium periodate followed by sodium chlorite oxidation. Because high 
molecular weight polymer is expected to show better builder performance ${ }^{15)}$, oxidativecleavage reaction of starch by sodium periodate was carried out at low temperature and for a shorter reaction time $(6 \mathrm{~h})$ in order to avoid molecular weight reduction by hydrolytic degradation. The dicarboxylation degree was controlled by the concentration of sodium periodate. Table 1 shows the typical oxidation conditions and analytical data for DC-starch.

\section{$3 \cdot 2$ Biodegradation of DC-starch}

BOD values were measured to evaluate the potential biodegradability of the polymers using a BOD tester with an activated sludge and a test polymer concentration of $25 \mathrm{mg} / \mathrm{L}$. It was found that the biodegradability of DC-starch was dependent on the amounts of the unreacted glucopyranose groups in the polymer. Figure 1 shows the relationship between 28d biodegradation $\left(\mathrm{BOD}_{28} / \mathrm{TOD}\right)$, calculated from the $\mathrm{BOD}$ values and the theoretical oxygen demand (TOD), and the dicarboxylation degree. Biodegradability is dependent on the dicarboxylation degree, or the content of unreacted glucopyranose groups, showing that the unreacted glucopyranose groups act as a biodegradable segment even in the polycarboxylate chain. However, highly dicarboxylated DC-starch was practically resistant to biodegradation even though the unreacted glucopyranose groups remained in the polymer chain. This fact indicates that a definite block length of successive glucopyranose units is necessary to react with the hydrolyzing enzyme in the polycarboxylate polymer chain. Among the corn, sago and tapioca starches used in this test, a slight difference was observed in the biodegradation results when compared using the same dicarboxylation basis. The biodegradability was better in the order of DC-corn, DC-sago and DC-tapioca. A BOD/TOD value of greater than $60 \%$ is regarded to indicate readily biodegradability ${ }^{19)}$. The dicarboxylation degrees of DC-corn, DC-sago and DC-tapioca showed that the 60\% BOD-biodegradation values were $25 \%, 20 \%$ and $15 \%$, respectively. The difference in biodegradability of these DC-starches is

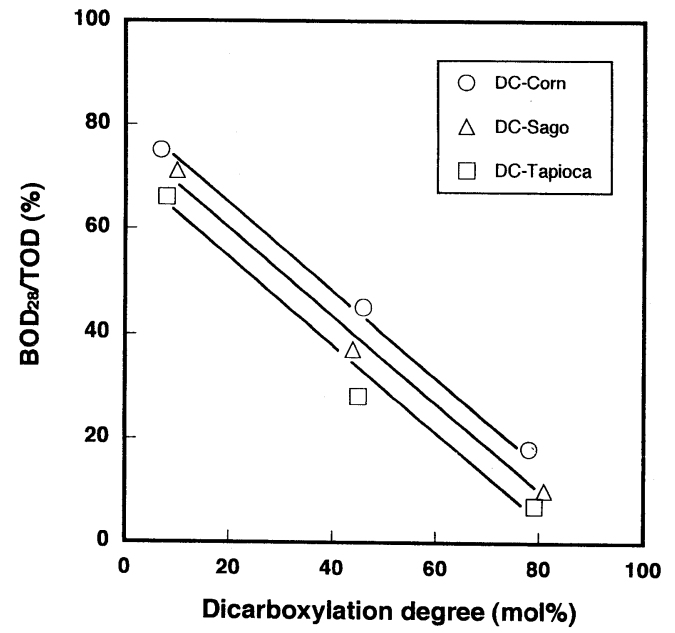

Fig. 1 Biodegradability (BOD/TOD) of DCCorn, DC-Sago and DC-Tapioca as Detemined by the Biochemical Oxygen Demand (BOD) as a Function of the Dicarboxylation Degree after $28 \mathrm{~d}$ Incubation. Biodegradability was calculated from BOD, as measured by the oxygen consumption method in a BOD tester using polymer concentration of $25 \mathrm{mg} / \mathrm{L}$ with activated sludge at $25^{\circ} \mathrm{C}$, and the theoretical oxygen demand (TOD).

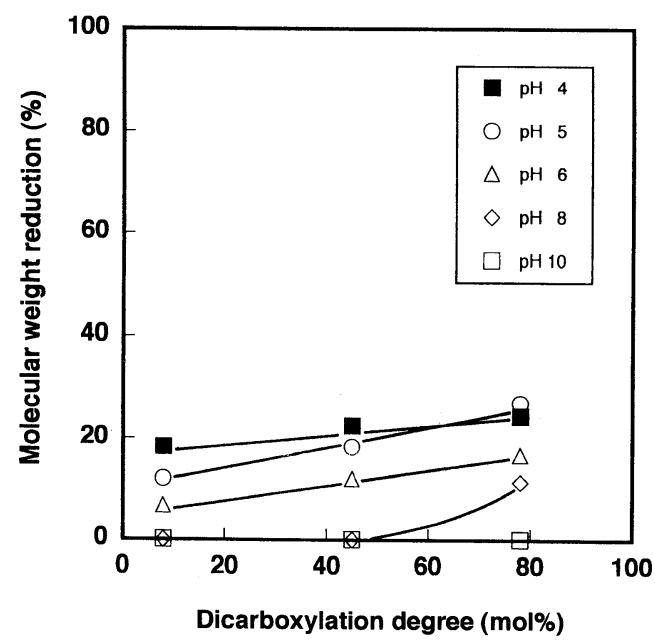

Fig. 2 Molecular Weight Reduction of $400 \mathrm{mg} / \mathrm{L}$ DC-Tapioca with Dicarboxylation Degree of 8,45 and $78 \mathrm{~mol} \mathrm{\%}$, Respectively, in 0.1 M Acetate Buffer ( $\mathrm{pH} 4.0$ and 5.0), Phosphate Buffer ( $\mathrm{pH}$ 6.0), Tris-HCl Buffer $(\mathrm{pH}$ 8.0) and Glycine-NaOH Buffer $(\mathrm{pH}$ 10.0) Solutions after $30 \mathrm{~d}$ Incubation at 30 ${ }^{\circ} \mathrm{C}$ in the Dark. 
probably ascribed to the microstructure of amylopectin in the starches. When compared to the dicarboxylated amylopectin from waxy corn as reported in the previous report ${ }^{17)}$, the dicarboxylation degree of 17 mol\% showed 60\% BOD-biodegradation.

\subsection{Hydrolytic Degradation}

The non-enzymatic hydrolytic degradability of DC-starch was evaluated in aqueous solutions of different $\mathrm{pH}$ values in sterile condition. Figure 2 shows the correlation between the dicarboxylation degree of DC-tapioca, as a typical of DC-starch, and the molecular weight reduction which is caused by the hydrolytic cleavage after $30 \mathrm{~d}$ incubation in various $\mathrm{pH}$ buffer solutions. It was confirmed that DC-tapioca was quiet stable against hydrolytic degradation under neutral and alkaline conditions after $10 \mathrm{~d}$ incubation at $.30^{\circ} \mathrm{C}$. However, after $30 \mathrm{~d}$ incubation DC-tapioca tended to be degraded slightly under acidic conditions of $\mathrm{pH}$ below 6 , and DC-tapioca with a higher dicarboxylation degree of $78 \%$ was more labile to hydrolytic degradation. These results indicate that the hydrolytic cleavage predominantly occurred at the acetal linkages of the dicarboxylated moieties other than the unreacted sugar moieties. Similar tendencies were observed for DC-corn and DC-sago, and among the DCstarches no significant difference in non-enzymatic degradation was observed. These results indicate that $\mathrm{DC}-$ starch is stable under washing conditions at a $\mathrm{pH}$ value of about $9^{22)}$. We previously reported that dicarboxylated alginic acid with a dicarboxylation degree of more than $42 \mathrm{~mol} \%$ showed significant molecular weight reduction at $\mathrm{pH}$ values below $8^{23)}$. It was also confirmed that DC-starch was much stable than dicarboxylated alginic acid against the hydrolytic stability. The difference in hydrolytic stability of DC-starch and dicarboxylated alginic acid will be ascribed to the carboxyl groups at the $\mathrm{C} 6$ position of alginic acid.

\subsection{Bulider performance in detergent formulation}

Polymeric carboxylates have been investigated as STPP substitutes and a number of polycarboxylates have been reported to give excellent builder performance in detergent formulations ${ }^{1,5), 9), 17)}$. The builder performance of DC-starch was evaluated on an equal weight basis in a heavy-duty detergent formulation on standard soiled cotton cloth samples. The detergency, expressed as a value relative to 10 for STPP and 0 for ODA, is shown in Fig. 3 as a

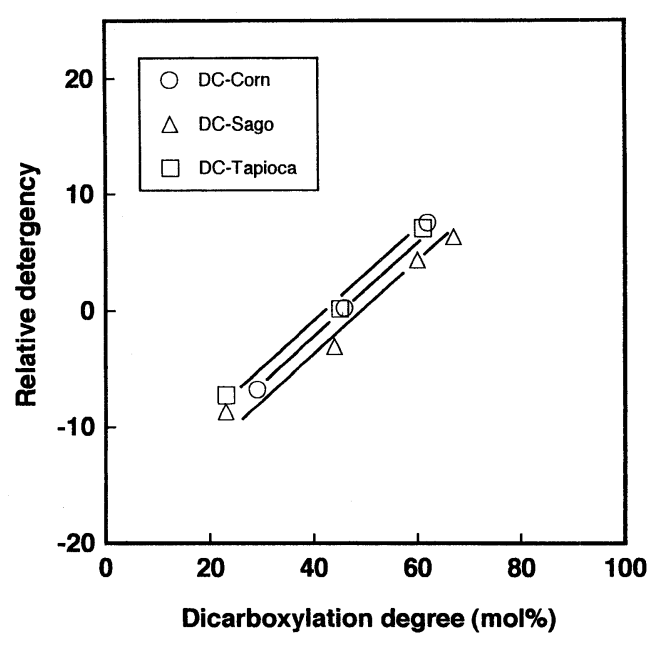

Fig. 3 Relative Detergency of DC-Starch Based on a Value of 10 for Sodium Tripolyphosphate (STPP) and 0 for Disodium 3Oxapentanedioate (ODA).

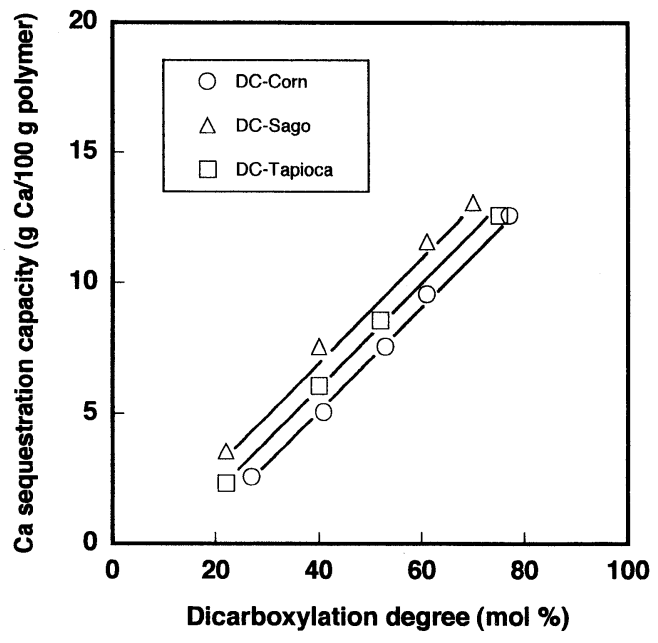

Fig. 4 Calcium Ion Sequestration Capacity of DC-Starch as a Function of the Dicarboxylation Degree.

Calcium ion sequestration capacities of STPP and ODA were 18.2 and 13.9 , respectively. 
function of the dicarboxylation degree of the DC-starch. It was found that the detergency was dependent on the content of the carboxylate groups in the polymer, and a clear relationship between detergency and the carboxylate group content was seen when compared on an equal weight basis. The polymers with high carboxylate contents showed better builder performance. Among the corn, sago and tapioca starches used in this test, no significant difference was observed in the detergency test. However, a slight decrease in detergency was observed compared to that of dicarboxyamylopectin ${ }^{17}$. Dicarboxyamylose from potato showed results similar to those of DC-starches ${ }^{5)}$.

Calcium ion sequestration capacity is an indispensable property for a detergent builder. Figure 4 shows the calcium ion sequestration capacity of DC-starch as a function of dicarboxylation degree. DC-starch with a high dicarboxylation degree showed good calcium ion sequestration capacity. A correlation between the sequestration capacity for calcium ion and the resulting detergency performance was demonstrated based on these data. DC-starches in this test and dicarboxyamylose from potato showed similar calcium sequestration capacities $^{5)}$.

\section{Conclusion}

Partially dicarboxylated starch sodium salt (DC-starch) from corn, sago and tapioca that contained unreacted glucopyranose groups was biodegraded according to the dicarboxylation degree or the content of the unreacted glycopyranose groups. DC-starch containing more than about 75 85 mol\% unreacted glucopyranose groups in the polymer chain showed excellent biodegradation. DC-starch with a high dicarboxylation degree was resistant to biodegradation but showed good builder performance in detergent formulation. DC-starch was quite stable under neutral and slight alkaline conditions. Among DC-starches from corn, sago and tapioca starch, no significant difference in hydrolytic degradability and builder performance in detergent formulation was observed.

\section{Acknowledgment}

We wish to thank Dr. Yutaka Tokiwa, National Institute of Bioscience and Human-Technology, MITI, Japan, for the stimulating discussions and supplying corn, sago and tapioca starches.

(Received : Feb. 13, 1996, Accepted : May 24, 1996)

\section{References}

1) M.M. Crutchfield, J. Am. Oil Chem. Soc., 55, 58 (1978).

2) S. Matsumura, S. Yoshikawa, Biodegradable Poly(carboxylic acid) Design, ACS Symposium Series, American Chemical Society, 433, 124 (1990).

3) M.B. Freeman, T.M. Bender, Environ, Technol., 14, 101 (1993).

4) S. Matsumura, M. Nishioka, S. Yoshikawa, Makromol. Chem., Rapid Commun., 12, 89 (1991).

5) S. Matsumura, M. Nishioka, H. Shigeno, T. Tanaka, S. Yoshikawa, Angew. Makromol. Chem., 205, 117 (1993)

6) S. Matsumura in R. Yamamoto et al. (Eds.), Adv. Mat. '93, V/A : Ecomaterials, Trans. Mat. Res. Soc. Jpn.. 18A, 451 (1994).

7) S. Matsumura, J. Synth. Org. Chem. Jpn., 50, 292 (1992).

8) G. Swift, J. Macromol. Sci. -Pure Appl. Chem., A 32 (4), 641 (1995).

9) S. Matsumura, K. Amaya, S. Yoshikawa, J. Environ. Polym. Degrad., 1, 23 (1993).

10) J.R. Daniel, A.C.J. Voragen, W. Pilnik, Starch and Polysaccharide, in Ullman's Encyclopedia of Industrial Chemistry, A25, 1 (1994).

11) B.T. Hofreiter, I.A. Wolff, C.L. Mehltretter, U.S. Pat. 2894945 (1959).

12) C.A. Wilham, T.A. McGuire, A.M. Mark, C.L. Mehltretter, J. Am. Oil Chem. Soc., 47, 522 (1970).

13) M.S. Nieuwenhuizen, A.P.G. Kieboom, H. van Bekkum, Starch, 37, 192 (1985). 
14) M. Floor, L.P.M. Hofsteede, W.P.T. Groenland, L.A. Th. Verhaar, A.P.G. Kieboom, H. van Bekkum, Recl. Trav. Chim. Pays-Bas, 108, 384 (1989).

15) Y. Dannoue, S. Matsumura, J. Jpn. Oil Chem. Soc., 42, 899 (1993).

16) S. Matsumura, R. Kobayashi, S. Yoshikawa, J. Jpn. Oil Chem. Soc., 40, 73 (1991).

17) S. Matsumura, K. Aoki, K. Toshima, J. Am. Oil Chem. Soc., 71, 749 (1994).

18) S.M. Neale, W.A. Springfellow, Trans. Faraday Soc., 33, 881 (1937).

19) OECD Guidelines for Testing of Chemicals, 301C, Modified MITI Test, Organization for Economic Cooperation and Development (OECD), Paris (1981).

20) O. Okumura, T. Tokuyama, T. Sakatani, Y. Tsuruta, J. Jpn. Oil Chem. Soc., 30, 432 (1981).

21) P. Kubelka, Z. Tech. Phisik., 12, 539 (1931).

22) M.S. Nieuwenhuizen, A.P.G. Kieboom, H. van Bekkum, J. Am. Oil Chem. Soc., 60, 44 (1983).

23) I. Winursito, S. Matsumura, J. Environ. Polym. Degrad., 4, 113 (1996). 


\section{日本油化学会誌本号掲載 論文要旨}

[総説 $]$
機能性タンパク質の配向制御

小山行一

新技術事業団「さきがけ研究 $21 」$

（干 300-26つくば市東光台 5-9-4 筑波研究コンソーシアム）

機能性タンパク質の人為的配向制御は将来のバイオデバイス開発に必要不可欠な技術である。本報告では，まず これまで試みてこられた感光性タンパク質の一般的な配向制御技術を概観した後, バクテリオロドプシンというき わめて安定な夕ンパク質を BS 抗体という一分子に 2 種の異なった結合サイトを有する特殊な抗体を用いて配向を 制御したわれわれの結果を紹介し，さらに免疫電顕法による配向状態を解析する手段についても述べ。

(連絡者: 小山行一) Vol. 45, No. 8, 715 (1996).

\section{[報文 $]$}

熱帯植物由来のデンプンをベースにしたポリカルボン酸塩の

生分解性, 加水分解性及びビルダー性能

Isananto WINURSITO • 松 村 秀一

慶應義塾大学 理工学部

（干 223 横浜市港北区日吉 3-14-1)

部分的ジカルボキシル化多糖をコーン，サゴ及びタピオカデンプンより合成し，それらの生分解性，加水分解性 及び洗剂配合物中でのビルダー性能について比較を行った。ジカルボキシル化デンプンナトリウム塩 (DC-starch) の生分解性はジカルボキシル化度に依存した。約 75-85 mol\% 以上の未反応グルコピラノース部分をポリマー鎖 中に有する DC-starch は優れた生分解性を示した。一方, ジカルボキシル化度の高い DC-starch は生分解性に 劣ったが, 洗剤組成物中で優れたビルダー性能を示した。コーン, サゴ及びタピオカデンプンから得られた DCstarch の中では，加水分解性及びビルダー性能に顕著な差異は認められなかった。

(連絡者 : 松村秀一) Vol. 45, No. 8, 723 (1996).

[報文］ヒル, Hirudo nipponia における Gal $\alpha 1-6 \mathrm{Gal}$ 及び Gal $\beta$ 1-6 Gal 構造を有するスフィンゴ糖脂質

杉 田 陸 海*1 ・森 川 曲 紀*1,*3 John T. Dulaney*2 ・岡 田 亜希子*1

*1 滋賀大学教育学部化学教室 ( $=520$ 滋賀県大津市平津 $2-5-1$ )

*2 テネシー大学医学部腎臟学教室 (951 Court Avenue, ‘649 D Memphis, TN 38163, USA)

*3 現住所 日本医学臨床検查所バイオアッセイ事業部 (†677 兵庫県西脇市中畑町 17-18)

チスイビル, Hirudo nipponia (環形動物, ヒル綱) の中性糖脂質には微量ながらグルコ及びガラクトセレブロ シド $\left(\mathrm{NGL}_{1}\right)$ も存在するが, 主要成分は Gal $\alpha$ 1-6 Gal $\beta$ 1-1 Cer $\left(\mathrm{NGL}_{2}\right)$, Gal $\alpha$ 1-6 Gal $\alpha$ 1-6 Gal $\beta$ 1-1 Cer $\left(\mathrm{NGL}_{3}\right)$, Gal $\alpha$ 1-6 Gal $\alpha$ 1-6 Gol $\alpha$ 1-6 Gal $\beta$ 1-1 Cer $\left(\mathrm{NGL}_{4}\right)$ の gala-6 系糖脂質である。これらの糖鎖構造 は, アノマー配置において, 今までに他の環形動物から見いだしている neogala 系列 (Gal $\beta$ 1-6 Gal) とは異 なっており, isoneogala 系列 (Gal $\alpha$ 1-6 Gal) と称することができよう。一方, 現在のところ環形動物を特色づ 